\title{
The Literary Achievements of the King Ashurbanipal (626 - 668 B.C)
}

\section{Samera Melad Amar Farag ${ }^{1}$}

Wan Kamal Mujani2

\author{
1,2Institute of Malaysian and International Studies, National University of Malaysia, 43600 UKM, Bangi Selangor, Malaysia
} ${ }^{1}$ samerafarag109@yahoo.com; ${ }^{2}$ inawan@ukm.my

\section{Doi:10.5901/mjss.2016.v7n4p}

\section{Abstract}

King Ashurbanipal, 668-626 BC was the last great King in the Assyrian Empire. His empire was extended to include Palestine, Phoenician kingdoms, Syria, Mesopotamia, Oaratu, Elam and Egypt. In his reign, the Assyrian empire had enjoyed the wealth, well-being and power. It was celebrated during his victories by establishing major buildings in the cities of Mesopotamia, especially the city of Nineveh. The remains of his palace were discovered in Tel Qongiq (Currently, it is called Mosul). This palace in its planning and its works represents the peak of the Assyrian genius in sculpture and architecture.The aim of the present study is to shed light on the great artistic heritage of a civilization which is one of the oldest and ancient human civilizations through the study and investigating its great artistic connotations. The study also aims to raise this issue to supply researchers and educators with some general information about the civilized critical period in the ancient history of Iraq with respect to the technical side when presenting Ashurbanipal's Arts and sculptures of a high-quality workmanship. A researcher depends on his study on the historical, analytical and descriptive method. They are considered as the finest curriculum that describes and analyzes the historical and artistic phenomenon. The Ashurbanipal's arts were characterized by a wonderful artistic achievement and the uniqueness of the Assyrian sculptor' deeds which were not matched by the works of the other models in the field of visible incarnations, large winged bulls and high statues. As the war was a source of the Assyrian kings' favorite pride, it attracted the sculptor's attention through the orders of Ashurbanipal to photograph the war in different aspects and with more details. The small lively views add to the tragedy of war to give an especial human touch. The most important thing in the Ashurbanipal's arts that draws attention and admiration are the scenes of the wounded animals. The Assyrian artists presented realistically and objectively the deadly pain that the animals going through or suffering from as in the scenes of the famous hunt which show aesthetic property that the artist realized through his human feelings towards these creatures. What distinguishes these scenes is that they attract whoever sees them through their splendid beauty. These scenes make up the natural conclusion to the art of collage which represents the concept of ownership in Mesopotamia, which reached its apogee and its regeneration under the Ashurbanipal's auspices.

Keywords: Ashurbanipal, Assyrian artists, Mesopotamia, civilization, sculpture, architecture.

\section{Introduction}

The nature of Iraq and its political history and cultural evolution all have formed its various arts. The architecture of the ancient Iraq had been influenced entirely by its geography in terms of the nature of the ground, and the type of soil and climate (Al Basha, n.d.). The northern part of the country differs from the southern part in its geographical nature. There is no doubt that the location of this part being close to the stones sources helped the sculpture to flourish or prosper in this part (Layard, n.d.), where the solid raw materials for sculpture were available in Assyria more than in Babylon for it is near to the the mountain regions and the location of the quarries alabaster being near to its capital, Nineveh. Moreover, this was due to the extension of its foreign possessions which are rich with stones and good metal appropriate for sculpture and formation. Assyrian status did not remain except a few types which do not agree with the potential of its time. However, its successful models were confined to the statues of kings and lords more than the statues of individuals (Salih, 1979). The large number of the discovered Assyrian palaces indicated that the most of Assyrian kings had attended or paid much attention and care to establishing such palaces as symbols of their greatness and a title of their power and richness. Their monuments have talked that their kings had been preparing artificial works as spoils, and that they had fetch the manufacturers and foreigners to implement many of the masterpieces 5 . The art and city moved along side by side with the victories of war. Two distinct stages in the Assyrian art have emerged: the first extended from the third century $B C$ to about one thousand $B C$. The second stage extended of the year of one thousand $B C$ until the fall of Nineveh in 612 BC (Barron, 2010). However, prior to this period, that is, the old Ages, what had emerged from the art of 
Assyria was all quoted or derived almost from the Babylonian Art in the south, yet the character of the Assyrian art begun its stage of independence and distinction in its style, methods and themes since the Assyrian mediator era (Baqar, n.d.).

The Assyrian art described many aspects of life including war, society and religion of its time, as well as its significance in the development of the techniques and skills in making the surfaces of monuments and walls which are covered with clay and porcelain, woods which are armored by metal foils, the seals and the rules of the statues and thrones and on the stone cornices which stand on the columns of the palaces and temples and explicitly through the carved images, which is written at the same time more and more a historic character. The Assyrian sculpture had a very closely related to architecture, as it was The aim of the art remained on these surfaces all over to celebrate satisfaction of the lust of the victory, love of pride and greatness of the kings (Salih, 1979). Since the military characteristic, which seized the Assyrian state, the themes of the sculpture were dominated by the military side, which made it differ from the religious characteristic that dominated the Babylonian sculpture. Both the military and religious characteristic had two origins in the Sumerian and Akkadian sculpture. Regarding the theme, the Assyrian sculpture was dominated by the narrative method. The primary purpose of the Assyrian sculptor was to narrate his stories clearly and explicitly through the carved images, which were at the same time written with more a historic character. The Assyrian sculpture had been very closely related to the architecture as it was mainly used for decorating both outside and inside of palaces and temples. The style of sculpture began to evolve as a result of exposure to the various influences that made Assyria a vast empire (Lioyd, 1961). The Assyrian art reached a higher degree of proficiency in the reign of Ashurbanipal.

\subsection{Masterpieces of Ashurbanipal's Palace}

The Ashurbanipal's Palace is situated in the northeast of Tel Qongiq (Salah, 1987). At such location holding the final form of Ashurbanipal's feature, the throne room, the reception rooms, the corridors and the bathrooms had been decorated by colorful and glamorous structures, which aimed to immortalize the King's achievements as a prince, a warrior and a great hunter (Barron, 2010). The study of the two Royal Palaces in Qhobjiq which had been built by Sennacherib and Ashurbanipal, respectively gives us the impression that they did not lose their previous function only as they were the heart of the legendary of property, but they also, through their two rooms that can be entered via every side, their entrances, pathways, yards and slopes as well as their prominent wall carvings and their photographic annals, aimed to display the King's historical achievements (Okasha, n.d.). The Assyrian palaces were architectural constructions suggesting to the viewer the huge strength of their founders. The triple arches were held in the entrances of Assyrian palaces.

Their walls were covered with a layer of glazed bricks with bright colors, and on both sides, the marble statues in the form of bulls with severed heads were established (Breasted, 1969). A piece of inscription preserved in the British Museum, which belongs to Ashurbanipal's Palace shows us an interface of a spacious building decorated with a frieze carried by four pillars and four columns. The base of the columns was built on the back of giant lions; both of them were walking to meet each other creepy. The engineer put at Lion's back pillows topped with the inscription, and then the base of the column. Among the ruins of Qongiq Palace, were found four bases of columns which are still in its place. There were also two winged oxen among the assets with human heads putting on the crown and on their backs, there is a spherical base decorated with geometric juts patterns (Bablun, 1987).

\subsection{Prominent inscription on the walls}

None had preceded the Assyrians in using the carved motifs on the stones of the walls except the Hittites. The Hittites' inscriptions reached only one meter high whereas the Assyrians, especially after getting the idea, increased in the breadth of coping as an exaggeration to show the greatness and luxury worthy of the Assyrian kings. The height of the views of the Assyrian palaces ranged from about two and a half to three and a half meters (Lioyd, 1961). The importance of this Assyrian method is attributed to the belief that these views represent the longest nonfiction area in the history of the old Arab Mashreq. The Assyrians adopted this method which differed from other methods. They made out of the recording of the details of the military events in an extended photographer bar a historical and decorative art which was easily understood and followed by others (Alam, 1975). It is noted that the Assyrian sculpture showed ingenuity in sculptures that revolve around showing the King's greatness and power, his victory over his enemies, his cruelty on his prisoners, his skill in war, his proficiency in hunting and the support of his Gods. However, in the synagogues and prayer rooms, the genre had a religious nature, but a few pictures reflected scenes of everyday life (Al Basha, n.d.).

It is worth mentioning that as a result of the Assyrians' engagement in the wars, they did not pay much care or 
attention to going deeply in religious affairs, so not many religious constructions were found for them, and what was found had been influenced by Sumerian style. It is also known that the Assyrian Kings cared for the construction of temples and ziggurats, which were one of the most prominent manifestations of the old Iraqi architecture. It is apparent that such less existing constructions may be due to the destruction caused to the country. Furthermore, the Assyrians did not take care of the construction of the graves since they did not believe in the hereafter. They also used to bury the dead of the royal family under the floor of the Royal Palace. What distinguishes the art in the old Iraq during the times of Assyrians specifically since the time of Ashurnasirpal is the use of winged bulls known as "Lamassu" to decorate the entrances of the Palaces and temples (Alam, 1975). These massive creatures that reached almost five meters height each used to stand at the entrance of palaces and temples, and the entrance was usually flanked by two of them. They used to stand in a way that their faces corresponded to the coming person, and their two sides confronted the two walls of the entrance (Alain, 1997). It is axiomatic that the purpose of carving these huge creatures at the entrances of the palaces was to exert effect on the visitor and impress him/her the of Assyrian kings' strength and greatness (Al Basha, n.d.). These were also intended to ward off evil spirits, at the same time, to give an architectural decoration. The King Ashurbanipal had ordered the construction of four large statues of silver bulls to be placed at the entrance of the Temple of Nabu in Borsippa, in addition to constructing three statues of gold, silver, and copper to represent him (Alam, 1975). In this regard, it should be noted that the Assyrian sculpture made most of these bulls having five legs, which is according to previous researchers' views, a phenomenon by which such sculpture could express both positions: standing and walking together. So whoever looks at them from the front side would see that they have four legs. It is also noted that the artist or sculptor did not only provide these statues with the most prominent manifestations of strong creatures, but he also added to them the combination of different situations (Ali, 1989).

The philosophical idea expressed by the bulls and lions through their venerable guard and the stability of their wings symbolizes the physical and static strength which has no doubt on its own. Through this idea, we find the man as the master of the creatures, the lion as the king of beasts, the bull as the vaccinater of herds and the eagle as the stronger bird (Tawfeeq, 1987). The artist's virtue lies in his addition of correct standards to this imaginative animal and in his installation of these elements taken from nature in order to create a superstitious creature or animal with harmonious shapes and whose shape or appearance does not shock the good taste (Alam, 1975). Antoine Murtkat stated that "these superstitious animals truly represent the architectural sculpture meaningfully. They are not only mural inscriptions that aimed at protecting the palace or temple of evil spirits, but these huge stone blocks are deemed as an integral part of the architecture building, and they used to perform a fundamental architectural function in supporting the cubs and the existing walls on it that make up the inner face on both sides of the massive doors "(Murtaqat, 1985). These objects combined both the art of engraving and stereotactic sculpture (Parrot, 1961).

\section{The Evolution of Assyrian Art in the Era of Ashurbanipal}

As shown by the inscriptions, we can identify three consecutive times of the Assyrian art. In the era of Ashurnasirpal, the pictures look energetic and bold, but they are few in terms of the number of the paintings which are moderate and full of realism (Hausz, 1967). We can also see that the artist in the Assyrian art has a western habit which is to cover a portion of his character with writings to explain the scenes. However, in the reign of Sargon and Sennacherib, the carvers gained richer experience and ambition, and therefore, in their drawings, there were many people who had one abstract purposeful goal of collective work. In addition, the scenes of the battles, the expedition of hunting, the worship of Gods and public works which were carried out by slaves became diverse, and the movement of people buzzed with its expressions and strength. At the end, the writings and drawing were put together. In the era of Ashurbanipal, an art which is closer to the nature was generated, and such art was also more corresponding to the principles of the correct engraving. In this art, we can see instead of the titans, short people who are making up a set of panels with different themes replete with freshness and movement (Bablun, 1987). We also witness a noticeable change in the imaginative and narrative style from the reign of Ashur Nasser Bal to the reign of Ashurbanipal. The scenes of the nineteenth century BC did not include only a few characters, and we can see in one of the panels that era, for example, two or three soldiers symbolizing hundreds of others, the artist lacking the rules of perspective, and there is also a lack of the ratios and standards (Okasha, n.d.). During the reign of Ashurbanipal, the relief sculpture was developed, and the sculptors were known for their precision of expression since they learnt about the punctilious details pertaining to the human and animal body and even plants. More than this, the artist during the era of Ashurbanipal seemed to be more aware of the subject of dimensionality (perspective) than his predecessors (Al Jadir, n.d.). 


\section{Assyrian Uniforms}

The prominent inscription in the palaces is the main source of our knowledge of the Assyrian uniforms. The sculptors had worked hard to distinguish between the Gods and the elves, and the king, the footnote and foreigners through the details of their clothes (Delaport, 1997). It seems that despite his royal Assyrian robe (robe with stringy belt which is in the form of rope and Alttiara (Crown which is doubled over the head) as Figure (1) carrying builders' basket over his head in an old ritual Sumerian Babylonian description, King Ashurbanipal's shape is closer in his composition to the Aramaic sex. There is no doubt that the influence by the Babylonian concepts which dominated the Assyrian concepts under the rule of Ashurbanipal clearly shows the picture in all its details (Okasha, n.d.). The Assyrian king is characterized by putting the crown on his head in the form of deficient cone topped with a fork and tightened with a bar having limbs which are hanging on his shoulders and sometimes reaching up his belt. Since the era of Sargon II, the embroidery had been given more attention.

The royal shirt used to have an edge and cilia. The inscriptions project the king putting on his neck a cluster of amulets and on the wrists and above the forearm bracelets and sometimes his appearance is completed by a bagger and a sword. The crown with a horn used to belong only to Gods, and the Gods and elves appeared the same as the other people, usually wearing short shirts and long peplos that do not cover the legs completely. There is one exception to this, that is the God Ashur was usually depicted in the form of two halves equipped with bow out of the winged disk, and this symbol even the origin, and sometimes the migraine form of god disappears except the winged disk only that remains seen, similar to the land of the Pharaohs (Delaport, 1997). The sacred tree in Assyria is another proof of depicting the Gods in their symbols. The inscription portrays the Assyrian king worshipping in front of the sacred tree, while the God Ashur appears at the top of the image (Arif, 1972).

\section{Arts of Battles}

The employment of art as an instrument for recording the history of the army and weapons in Mesopotamia is dated back to the very ancient roots (Ali, 1989). The art of the battles had reached its peak in expressing tournaments and epics to in the modern Assyrian era coincided with large and overwhelming victories over their enemies, which were achieved by Assyrians in various quarters. In the reign of Ashurbanipal, for the first time, in the relief sculpture, there was an emerging scene of large crowds tightly knit in fierce battles1.The Assyrian inscription is rich with its numerous paintings scattered among museums in the world, and therefore, we will try to shed light on the most famous art paintings from the era of Ashurbanipal that hold a great historical value as well as technical mastery.

\section{The Scene of Assyrian and Elamite War}

The Ashurbanipal's battle against the Elamites on the River of Olay was one of the most famous ancient historical battles. The Assyrian artist depicted this battle in the painting (Ali, 1989) as in Figure (2) showing that the Assyrian soldiers are attacking the city of Hmong, and having destroyed it (Tawfeeq, 1987); they leave it after taking up the spoils. It is possible to observe the different movements which are full of vitality performed by the king's soldiers while destroying the city (Alam, 1975.). In this painting, the artist has depicted the Assyrian violence and ferocity attack meticulously as he portrayed a row of vehicles followed by the infantry in penetrating the ranks of the enemy, scattering them and strucking terror and panic in the hearts of their enemies. At the far end of the scene, we see the soldiers of the enemy with their horses being swept away by the water of the Olay River after the Assyrians had surrounded the enemy from all directions and made the enemy taste the bitterness of defeat (Ali, 1989).

In the largest part of the image, there seemed to be the city with high-rise buildings including houses and palaces, etc. The soldiers stopped on its tops, carrying in their hands the hoes used to destroy the buildings that littered its stones, while we see the flames and the fire as a result of the fires that the soldiers ignited in the city. Furthermore, the figures of the soldiers appeared more clearly than ever before, and we see the plot of the configuration clear in the elements of the picture and the use of vertical, horizontal and oblique lines behind the curves and plant items. We see here how the artist controlled the composition of the picture in general and displayed the movement, vitality and the sense by utilizing the geometric and floral shapes to give us a comprehensive picture (Al Masri, 1976). King Ashurbanipal took the picture of celebrating the victory against the king of Elam Tioman Tioman in view of the palace garden in the city of Nineveh, which is known as a garden view (Murtaqat, 1985). Figure 3 shows that the King Ashurbanipal is holding a cup in his hand (toast of victory) besides his wife who is sitting on a reclined seat, speaking to each other. The clusters of grape are covering them, the tree branches are intertwining above them, being sourrnuded by the birds with the music playing. The 
head of Tioman is also seen hanging on a branch, not far from the tree and bleeding (Chatelet et al., 1985). This indicates that the kings of Assyria had not forgotten the manifestations of cruelty even in their leisure hours and their fun. Such image has another indication as it is one of the rare scenes in which Assyrian women appears (Alam, 1975). It is noted in this scene that the Queen Visage looks like males as her coiffure is just like men's style. She also appears putting the crown on her head, and wearing luxurious clothes embroidered and covered with precious stones, but the artist refused to expose any part of the body, and her arms were covered with cloth and ornaments while they are usually uncovered for men (Bablun, 1987).

The landscapes were carved in rows above each other, and the effect of this is that the place became narrow which are accurate in representing resulted in carving on the smaller size. The sculptor tried to the scene, and the implementation was at a high level of proficiency and much more attention was paid to the inscription (Delaport, 1997). A good example of this is the connection of one topic on three rows to the scenes of the Arab Assyrian wars, scenes rippling with movement and hit-and-run, speed where the Assyrians appeared to be fighting by spears and arrows, walking and riding camels. In such scenes, every two soldiers ride a camel, one of them leads it with his stick and the other shutting his bow in front and back, and the camels run in a wonderful speed to save the riders and survive itself in a way that they look like jumping or flying (Salih, 1979). In any case, these pictorial monuments allowed us to the access to the most accurate details of the equipment and weapons, and the ways they are used. This is something that cannot be illustrated by the texts alone (Lioyd, 1993). While the Assyrian artist depicted the battles in all details, he also took care of the life in the camps though it did not belong to the battle itself because he portrayed a soldier preparing the officer's mattress and putting a jar of water near it in order to drink, or the scene of military such as cavalry, infantry, and the musicians were playing. However, we see that the artist has neglected the other side of the aspect of life which represents the side of peace including the security and complacency but in the small part of it. He, in depicting this little thing, has not forgotten to confer on those paintings what dramatizes and freak of brutality and ferocity, as previously seen in the scene of garden (Okasha, n.d.). Yet, at the same time, we cannot not deny the Assyrian artist's interest in the landscapes such as forests and rivers though it was represented with strange errors compared to the normal things. For instance, in the midst of water, the fish seem bigger than the ships, and in the forest, the birds appear with the size of trees and fishermen, and so on. While in the era of Ashurbanipal, the nature was depicted, it had been neglected before (Bablum, 1987). The bushes of swamp appeared, rivers and canals were filled with fish, palm trees, figs and all the elements that determine the geographical framework of the photographic subject. Therefore, it seems that the art of Ashurbanipal was closer to the truth than ever (Okasha, n.d.).

\section{Scenes of Hunting}

The subject of human's struggle with wild animals that we see on the walls of the palaces had reached its peak of maturity and creativity in the reign of Ashurbanipal. During this time, hunting wild animals was a defensive way as it was a royal sport. It was necessary to always defend the herds of sheep and cattle against predators. In the scenes of hunting lions and other animals, the Assyrian sculptor deliberately took an advantage of the full front side of the wall to provide a continuous process of hunting narrating a complete story of one day of King's hunting trip (Ali, 1989). There is a mural showing us in details the hunting trip including its startup moment in the morning, its hour of returning back after days and the standing dogs surrounding the cages, swooping on them as if they were trying to fight the monsters in order to set them again to their places so as not to get away. We also see the King who is passionate in hunting being passionate in war, riding his vehicle. In addition, we see the lions docking with men angrily and snarling, and one of them flicked on the royal vehicle while the King halted unperturbed and unflappable, launching his lance at its body, hence, causing lions eventually to fall injured one after the other and felling a contort (Figure 4). We also see the King standing steadily against the lioness that he has not taken revenge on it for its ferocity except entering three arrows in its body, but it remained standing on its front legs, trying to leapfrog (Okasha, n.d.).

\section{The Scene of the Wounded Lioness}

The Assyrian artist depicts (Figure 5) the lions being fussy, frowning tusks, highlighting its tentacles and pulling the paralyzed part of its body after having been injured by the arrows despite that its backbone had been broken as it was penetrated by an arrow from one side to the other side. This artistic image also portraits the injured lioness with its bleeding wound and before its last breath, we can see that monster re-collecting or re-gathering its power valiantly to stand on its front feet and roaring its last roar(Chatelet,1985). This artistic painting is considered as one of the most important and outstanding sculptures which is currently displayed in the British Museum. Although the artist used the 
modified decorative lines in portraying the different parts of the lioness such as the face and muscles, he was able to convey, through his skill, the idea of the fighting nature that never surrenders. The curved flowing lines provided a kind of public harmony as they reflect the movement of the creature. Thus, the Assyrian artist, through his talent, was able to portrait the dead creature as alive for the viewer (Al Basha, n.d.). In order to represent a tragic situation in its reality, the artist used to accompany the king in his hunting trips to the middle of the desert where there were predators and he used to trace the scenes very closely(Bablun,1987), hence, showing us such senses most precisely as if they were in reality.

\subsection{The scene of chasing the zebras}

The Assyrian artist depicts (Figure 6) a number of zebras merely to escape and the dogs are chasing them as the arrows hit and killed some of the zebras while hitting and entering in some other zebras' bodies. The artist was capable of representing the animal in a way of simulating of the nature by combining both modeling and modulating. The picture is also full of vitality and is indicative of the strength of observation where the movements and situations seem diversified. What is attractive in that painting is the scene of the animal turning its head back fearing for its small redneck while the ferocious dog almost managed to catch it (Al Basha, n.d.). Thus, the artist's passion in the animals and his knowledge of the composition of their own bodies seem clear, as the strength of his sensitivity appears in capturing the mare returning back fearing for its small pony that was haunted by dogs (Bablun, 1987).

What can be seen in the scene previously mentioned is a swab of pathos and sympathy because a person sympathizes with a lioness when it dies, and with the female of the zebra being forced to abandon its small zebra. The Assyrian artist finds a fun in portraying the horse like the standing shaky zebra chased by the fisherman, the horse which throws itself into the fray swooping on the enemy after being riden by a struggling Knight, or the horse being coupled to the royal vehicle trampling by its feet on the bodies or even dragging the tank carts of the booty to Assyria which were captured from the enemy. Here, the cleverness of the artist who has been gratitude by the naturalists lies for using such inscriptions to assist them in determining the types of horses used by the Assyrians at that time (Bablun, 1987).

The artist shows us other inscriptions with similar success in implementation. These include lions standing around the King's vichel or lying in the spacious lane to relieve carelessly its twisted limbs with flexibility and sincerity. Despite the fact that the artist does not show in these scenes any interests in the background of the image in which he distributed the animals, one does not feel this lack of high accuracy of drawing out these animals with an interest to clarify the different facial impressions and emotions (Alam, 1975). We can also notice that the herds of zebras, wild horses and hunting dogs have been depicted in a way that tells us the sculptor has watched and studied the characteristics of animals in conditions of security, and hours of dismay. Its images are free of the stop lines and straight floor, hence, allowing showing the depth in its landscapes (Salih, 1979). There is no doubt that the modern and old art has not carved the animals as successfully as the Assyrian art did. The stone tablets repeat, in front of the eyes, boring views that represent war and hunting, but the eye never gets tired of looking at the movement of the strong animals and its natural reluctance as well as its simple image that is not attitudinized as if the artist who has been forbidden to portray his masters in their reality and individuality has endowed all his work and cleverness to portray animals (Durant, 1988). The Assyrian artist's study of the human forms was not a direct study, but it was not so in the representation of animals. The Assyrian sculpture shows elevation in the transfer of images of animal species, and in this, it is very ennobled on the Egyptian art even reaching a degree of perfection in the reign of Ashurbanipal, which enables it to be compared with the best Greek artistic production (Bablun, 1987). We do not feel the high-level of technical skill in every work of these works of art, but we recognize immediately a touch of genius, which cannot be ignored, suggesting that there is an influence of Ashurbanipal himself on the artists whom he had sponsored(Okasha,n.d.).

\section{The Assyrian Furniture and Decorative Works}

No people in the ancient times had loved luxurious furniture as much as the Assyrians did. They carved their furniture very carefully, as a whole precious bronze ware. The inscriptions show us their furniture made of wood which radiates with the Assyrian ingenuity and reveals to us the very wealthy people among whom furniture had received the forefront (Bablum, 1987). The furniture in Mansions had been very luxurious in the first millennium of the birth of Juses and during the passage of time; it became more luxurious and decorative (Delaport, 1997).

The inscription, which represents Ashurbanipal offering wine to the Gods (Figure 3) and being accompanied by one of his wives shows us the furniture of the inner rooms of the palace where the King lay on the divan, and the queen sat on a bench, putting her feet on a footstool and in front of her, there was a table. Are such bed and table ended by the lion's claws, and this chair which is laden with carvings and covered with ivory evidence of the Assyrians genius in the art 
of engraving and decoration (Bablun, 1987). The Assyrian kings had a passion for cutting-carved ivories and considered it as their favorite art. Such pieces have been closely associated with the furniture industry (Al Jadir, 1987).

The carpenters of furniture exploited the two animal and plant kingdoms with an amazing skill in the decoration of tables, chairs , cloak and umbrellas, where we find everywhere mouths gaping, lions' claws, goats , cheetah and oxen which were used haphazardly, but in full coordination and high-taste. The roses, wreaths, gyri, plots, flowers and geometric shapes are all varied to indefinitely in a true equilibrium, and they were made better neither in Egypt nor in Greece, or anywhere else. In addition to these scattered inscriptions on the walls of palaces, there are secondary inscriptions which radiate such the Assyrian ingenuity and which are inscriptions used for adorning the carpet on the thresholds of palaces. The most important example of these is the large slab which was found in Qongiq and in which the brides of the Nile and roses as well as blooming pearls, flowers and harmonious engineering drawings are mixed. It seems to be as much excellent as possible to man to imagine in the field of decorative engraving as shown in Figure (7).

The bottom line is that the Assyrian sculpture has succeeded in the inscription, and in the decoration that require accuracy and strength (Bablun, 1987). It attests to the high-skill in the exploitation of the decorative style in the representation of the nature and reality. It is important to point out at the important issue which is the use of colors by the Assyrians in their carvings (Al Basha, n.d). Some are likely that the sculptures were not all discoloration, but the colors were used to illustrate some parts and details such as the eye and arms, leaves, flowers and some clothes (Al Basha, n.d). In relation to the Assyrians use of bronze, the perfection provided by the Assyrian artists in making some bronze utensils makes these masterpieces as a real type. In Nineveh, metal racks some of which had been engraved with gold and silver were found. Through the internal part of these images, there were common center areas to the stellar flower and inconsistent corona, and forms with prominent lines (Bablun, 1987). It should be noted that the use of bronze in making the monument is a purely Assyrian art despite its transition to outside areas (Arif, 1972).

Before we sum up this subject, it should be pointed at the global description characterizing Assyria since the establishment of their state on the virtue of the its various external contacts, specially being affected by the artistic style in the Levant, the Egyptian art and the arts of the Aegean Sea and Minor Asia (Al Basha,n.d.). The decorative metal utensils were imported from Phoenicia, and the manufactures ivory were imported from Egypt (Prested, 1969). We see that many decorative paintings by the Assyrians artists were originally Egyptian. In addition, the pieces of furniture which are inlaid with ivory and ebony made by the Phoenician workers were also revealing to be originally Egyptian (Bablun, 1987). Some of the Assyrian utensils are similar to the Cyprus Phoenician utensils in the form and minerals, inlaid with gold, silver and theme. We cannot also overlook the impact on the Assyrian art which was resulted from the invasion of Laminating to the north of Iraq and the idea of the participation of Hittites in animal drawing especially horses which were escaping away because of their knowledge of them and their ability to study these horses and understand its sense and desire (Okasha,n.d.). However, the fictional characters of humans with wings or men with the heads of birds were not known by the Phoenicians or the Hittites except that they consistently appeared in the arts of Mesopotamia, which likely supports that, the participation of the Assyrian artist, who designed these paintings, in implementing this work of art.

The idea of recording the battles of war may be derived from the same landscapes that cover the walls of the temples of the Ramesseum and the city of Habu in Thebes (Orthmann, 1975). The Phoenicians, who had a particular fondness in imitating the Egyptian art, may have transferred the idea of the topics of the Assyrians one. However, what is purely Assyrian includes protruding seals in the hands of the priests or jinn as shown in the inscriptions, which distinguishes heads of lions, elegant roses adorning the inside or sides of the utensils or even the front of the handles (Bablun, 1987).

What attracts the attention is that this art was found only in royal palaces, which are likely that the Kings had used the skilled makers from all over the Assyrian Empire (Alam, 1975). It is worth mentioning that the inscription of one painting was rarely made by one single artist, so we encounter images that reflect varying technical capabilities. We also find the chisel of the teacher as a moratorium on the main persons, the royal procession and the officers around him, while the work in the secondary details (the bodies of the enemy, the convoy of prisoners and the background of the landscape) were authorized to the students (Bablun, 1987). What we have mentioned about Ashurbanipal's arts through the inscriptions of interior palace can lead us to state that if we took at it as whole, we would found that it was made to glorify the King, only. The king represents the life of his people, and nothing had been working and or had been done without his hand or his command, and that we do not see anywhere inscriptions best than these in terms of showing us the power of the king.

\section{Conclusion}

The work of relief sculpture in the era of Ashurbanipal has a real beauty. Mesopotamia represents the greatest 
achievements of the Assyrians and the most originality. From this careful reading of Ashurbanipal's mural, we find a splendor of artistic achievement in the embodiment of the atmosphere of the battles and in the topic of wounded animals which provoke the sense of the viewer with sympathy on the comic animals in their climax of tragedy. We also notice that in this era there was a significant and technical evolution in the field of relief sculpture with sculptor's increasing ability to show the required influence in different situations and to show many details in the forms and shapes of human, animal and plant. This evolution was achieved in large sculptural pieces and gave it a unique aesthetic philosophy.

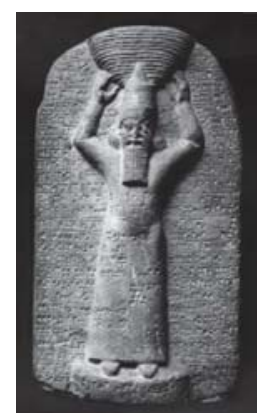

Figure 1: Ashurbanipal, Last of the Great Kings of Assyria

Figure 2: The Wars of Ashurbanipal
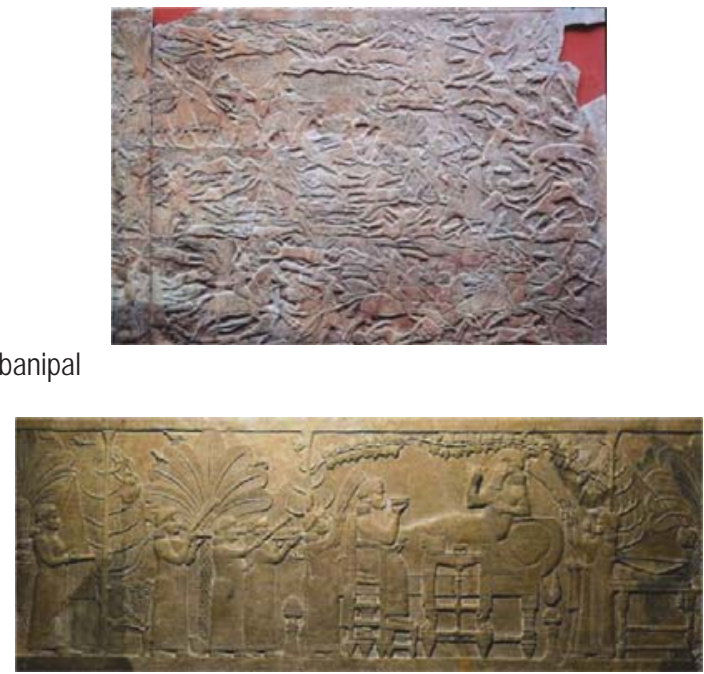

Figure 3: Assurbanipal and His Queen in the Garden

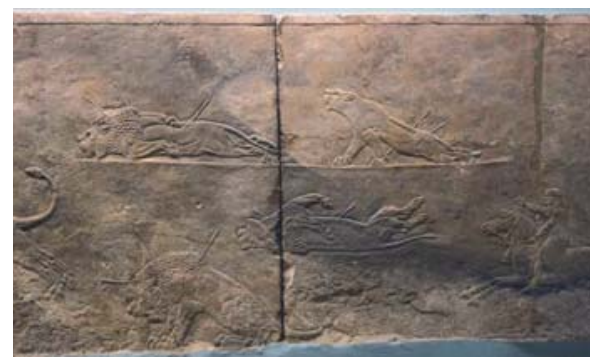

Figure 4: Ashurbanipal Hunting Lions 
Figure 5: Injured Lion
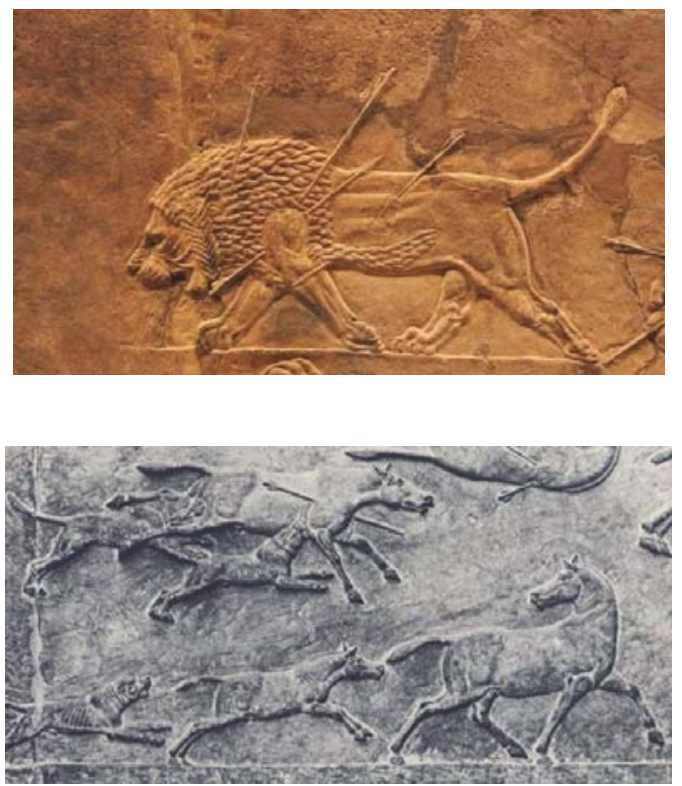

Figure 6: Chasing the Zebras

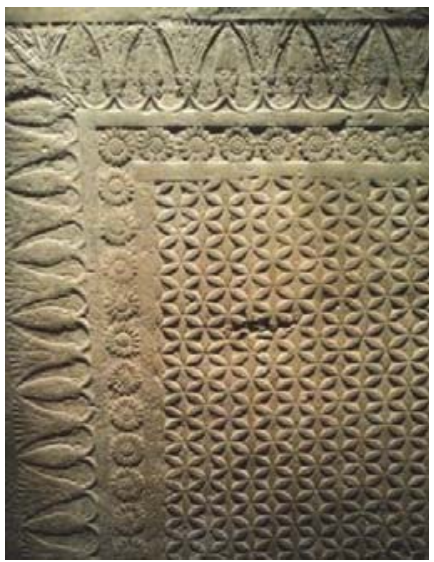

Figure 7: Assyrian Stone Carpet

\section{References}

Al Basha, H. (n.d.). The old arts in Mesopotamia. Al Darr AL Arabia library for books.

Al Jadir, W. A. (n.d.). Sculpture in Al Sulalat era: Iraqi civilization (Vol. 4).

Al Masry, K. A. (1976). The History of art in the ancient eras. Egypt: Dar Al Maraf.

Alain, S. (1997). Histoire de l'Art: Préhistoire et antiquité: Paris: Flammarion.

Alam, N. I. (1975). The middle east arts and the ancient world. Cairo: Dar Al Ma'arif.

Ali, F. A. (1989). From Sumer tablets to Al Tawrah. Baghdad: Dar Al Shu'un Al Thaqafea.

Arif, A.S. (1972). The ancient art schools. Beirut: Darr Sadr.

Bablun, A. (1987). The eastern archeology. Dar Gross Press, Tarablus: Dar Hikmit Sharif.

Baqar, T. (n.d.). An introduction in the history of ancient civilization (Vol. 1). Baghdad: Dar Al Kutub for printing and publishing.

Barron, A. E. (2010). Late Assyrian arms and armour: art versus artifact. University of Toronto, Toronto, Canada.

Châtelet, A., \& Groslier, B. P. (1985). Histoire de l'art: Larousse.

Delaport, L. (1997). The Mesopotamia (Assyrian and Babylonian Civilization) (M. Kamal, Trans. 2 Ed.): The general committee for 
books.

Hawaz, A. (1967). Art and society through history. The general central library: Cairo University.

Layard. (n.d.). Nineveh and its remains. London.

Lioyd, S. (1961). The art of the ancient Near East. Thames and Hudson.

Lioyd, S. (1993). The remains of Mesopotamia from the old Era up to the Persian invasion (M. Talab, Trans.). Dar Damascus for printing and publishing.

Murtaqat, A. (1985). Tamuz the art of sculpture and its places in the ancient east (T. Sulayman, Trans.). Damascus: Darr Al Majad for Al Nasher and printing services.

Murtkan, A. (1987). Arts in the ancient Iraq. General Education administration: Al A'deeb Al Baghdadya Press.

Okasha, T. (n.d.). The Iraqi art of Sumer, Assure and Babil. Arabic institution for publishing and studying.

Parau, A. (1980). Bilad Assure (Nineveh and Babil) (E. S. e. al., Trans.). Dar Al Nasheed.

Parrot, T. (1961). Ashur librairie. Gollimar Paris.

Prested, J. H. (1969). The civilization victory (history of the ancient east). Cairo: Egyptian Anglo library.

Salih, A. A. (1979). The old near east (Egypt-Iraq) (3 ed. Vol. 1). Cairo.

Salih, Q. R. (1987). The archaeological detection in Iraq. Baghdad: Dar Al Kutub for Printing and publishing.

Sehnapp, A. (1997). Preehistare et antiquite, Flammarion: Paris.

Seton, L. (1961). The Art of the ancient near east .Thames and Hudson.

Tawfeeq, S. (1987). The history of arts in the ancient near east (Egypt and Iraq). Dar Al Nahdha Al Arabiya. 